This PDF is a selection from a published volume from the National Bureau of Economic Research

Volume Title: U.S. Engineering in a Global Economy

Volume Author/Editor: Richard B. Freeman and Hal Salzman, editors

Volume Publisher: University of Chicago Press

Volume ISBNs: 978-0-226-46833-4 (cloth); 978-0-226-46847-1 (e-ISBN)

Volume URL: http://www.nber.org/books/free12-1

Conference Date: September 26-27, 2011

Publication Date: April 2018

Chapter Title: Bridge to Permanent Immigration or Temporary Labor? The H-1B Visa Program Is a Source of Both

Chapter Author(s): Ron Hira

Chapter URL: http://www.nber.org/chapters/c12691

Chapter pages in book: (p. 263 - 283) 


\section{Bridge to Permanent Immigration or Temporary Labor? The H-1B Visa Program \\ Is a Source of Both}

Ron Hira

\subsection{Introduction}

Many members of the popular press, pundits, business and university leaders, and policymakers conflate and often confuse guest worker visas, such as the $\mathrm{H}-1 \mathrm{~B}$, with permanent immigration. ${ }^{1}$ Carly Fiorina, an advisor to John McCain's presidential campaign in 2008 and former chief executive officer (CEO) of Hewlett-Packard, responded to a question about H-1Bs during the campaign this way, "It is in our economic interest to have really smart people wanting to come here. And so what's wrong with the H-1B visa system today, among other things, is that we curtail that program so tightly that the limits that Congress allows for $\mathrm{H}-1 \mathrm{~B}$ visa entrance are usually filled within one week. So we have to find a more practical system for allowing smart, hardworking people to come into this country and it should be our goal to get them to stay here forever" (Bomey 2008). Reading the quote, one might expect that expanding the $\mathrm{H}-1 \mathrm{~B}$ program is the critical change to immigration policy that is needed in order to keep skilled workers here permanently. While permanent residence allows foreign nationals to live and work in the United States permanently, guest worker visas like an H-1B allow them to live and work in the United States only temporarily (not "forever") and under circumstances that restrict their ability to stay in the coun-

Ron Hira is associate professor of political science at Howard University.

For acknowledgments, sources of research support, and disclosure of the author's material financial relationships, if any, please see http://www.nber.org/chapters/c12691.ack.

1. Some justify expansion of the H-1B program on the grounds that immigrants found new companies in the United States (Friedman 2009; Washington Post 2008). However, by regulations H-1Bs are not allowed to found a company. 
try if they do not keep their position. These circumstances sometimes put guest workers in a precarious position that invites their exploitation, creates insecurity for them, and undermines the integrity of the labor market. These consequences are caused by the design of immigration policies - a combination of loopholes and the fact that employers, rather than workers, control the work permit.

While some $\mathrm{H}-1 \mathrm{~B}$ visa holders gain permanent residence, many employers use the H-1B program solely for employing temporary immigrants, and their share of the H-1B visa numbers is large and increasing. This chapter shows that the H-1B guest worker program has bifurcated, with some employers using the $\mathrm{H}-1 \mathrm{~B}$ visa program as a bridge to permanent immigration while most top users of the $\mathrm{H}-1 \mathrm{~B}$ visa programs sponsor very few of their workers for permanent residence. Firms that use the program principally to offshore work to lower-cost countries use H-1Bs as temporary labor. They pay lower wages, have flatter wage distributions, source a much higher share of their $\mathrm{H}-1 \mathrm{Bs}$ from India, and have a higher proportion of their H-1Bs with no more than a bachelor's degree compared to firms that sponsor $\mathrm{H}-1 \mathrm{Bs}$ for permanent residency. There are differences in $\mathrm{H}-1 \mathrm{~B}$ use in sponsoring permanent residence even within different divisions of the same company. Given the relatively low wages that can be paid to $\mathrm{H}-1 \mathrm{~B}$ visa holders, firms have increasingly used the program for temporary labor mobility to transfer work overseas and to take advantage of lower-cost guest worker labor rather than attracting the "best and brightest" for permanent immigration. High-skilled immigration policy discussions should recognize these empirical realities.

\subsubsection{Permanent Residence versus Guest Worker Status}

The distinction between a permanent residence visa, commonly called a green card, and guest worker status is substantial and has important economic and policy implications, particularly for the high-skilled labor market (and especially in the information technology and engineering labor markets). Permanent residents enjoy similar employment rights as American citizens. They are eligible to apply for nearly all the same jobs as citizens, and they can stay in the United States even if they are out of the labor market. On the other hand, H-1B visas are work permits held by a specific employer for up to six years. The employer holds the work permit so it can revoke the visa at any time by terminating the worker, which means that the worker must leave the country immediately. ${ }^{2}$ The H-1B workers can switch employers only if they can find another employer willing to sponsor them for an $\mathrm{H}-1 \mathrm{~B}$. In contrast to the employment rights of citizens and permanent residents, $\mathrm{H}-1 \mathrm{~B}$ rules place most of the power in the hands of the employer

2. Generally, workers who are laid off try to switch status to a nonwork temporary visa, such as a tourist visa, while they search for work. 
and create opportunities for leverage that allows some employers to exploit guest workers for whom they obtained an H-1B. Some, such as former Secretary of Labor Ray Marshall, have described this employment relationship as indentured (Marshall 2009, 37).

This type of exploitation has been widely reported in the press. A 2009 Businessweek cover story profiling the exploitation of H-1B workers was called, "America's High-Tech Sweatshops" (Hamm and Herbst 2009). Also in 2009, the Louisiana Federation of Teachers filed a complaint on behalf of teachers brought in from the Philippines, who were being held in "virtual servitude." Their employer intimidated them, charged exorbitant and unnecessary fees, and forced them to live in roach-infested, run-down apartments leased by the employer (Toppo and Fernandez 2009). This type of exploitation is not new. Back in 1993, CBS's 60 Minutes television show aired a story on $\mathrm{H}-1 \mathrm{~B}$ computer programmers who were contracted out to Hewlett-Packard for $\$ 10$ per hour, nowhere near what the company would have to pay permanent residents. ${ }^{3}$

Current U.S. immigration policy favors family-based immigration, which accounts for about 65 percent of the approximately one million new permanent immigrants admitted annually. Many skilled immigrants come through family-based immigration, but $\mathrm{H}-1 \mathrm{~B}$ visas serve as important sources of skilled permanent immigration. A majority of permanent, employmentbased immigrants were originally H-1Bs. The visas are "dual intent," meaning that while visa holders are here temporarily on nonimmigrant work permits, their status does not preclude them from staying permanently if their employer chooses to apply for an employment-based permanent immigration visa. Employment-based immigration accounts for approximately 15 percent of permanent immigration, and some researchers estimate that 62 percent of employment-based permanent immigrants began as $\mathrm{H}-1 \mathrm{~B}$ temporary workers (Jasso et al. 2010). To say that the H-1B accounts for a majority of employment-based permanent immigration is not, however, the same as saying that most $\mathrm{H}-1 \mathrm{Bs}$ become permanent residents. Many H-1B workers are never sponsored for permanent residence. The H-1B workers cannot sponsor themselves for permanent immigration. Only employers have that authority and exercise it at their discretion. For those guest workers who want to stay permanently, it puts additional power in the hands of their employers, power that employers have lobbied to maintain. During the 2007 debate over comprehensive immigration reform, businesses fought against an allocation of self-sponsored, high-skill immigrant visas based on a merit point system, arguing that they, as employers know best what kind of workers are needed as permanent residents in the United States (HennessyFiske and Puzzanghera 2007). 


\subsubsection{H-1B Visas: Preimmigration versus Temporary Worker}

The $\mathrm{H}-1 \mathrm{~B}$ is a nonimmigrant visa under the Immigration and Nationality Act (INA), section 101(a)(15)(H). It allows employers within the United States to temporarily employ foreign workers in specialty occupations. The regulations define a "specialty occupation" as requiring theoretical and practical application of a body of highly specialized knowledge in a field of human endeavor including, but not limited to, architecture, engineering, mathematics, physical sciences, social sciences, biotechnology, medicine and health, education, law, accounting, business specialties, theology, and the arts, and requiring, with the exception of fashion models, the attainment of a bachelor's degree or its equivalent as a minimum. Likewise, the foreign worker must possess at least a bachelor's degree or its equivalent and state licensure if required to practice in that field. The $\mathrm{H}-1 \mathrm{~B}$ work authorization is strictly limited to employment by the sponsoring employer. The duration of the visa is three years, extendable to a maximum of six. However, this duration can be extended indefinitely beyond the six years, in one-year increments, if the employer is sponsoring the $\mathrm{H}-1 \mathrm{~B}$ worker for permanent residence.

\subsubsection{The Data}

The H-1B is a large guest worker program, admitting 124,326 new foreign workers in fiscal year 2014 alone (U.S. Department of Homeland Security 2015). While no one knows the exact number of $\mathrm{H}-1 \mathrm{~B}$ holders in the United States at any one time, because the government does not track those numbers, estimates are in the range of 650,000 . For the H-1B data, I use the I-129 petitions approved by USCIS, which I received via a Freedom of Information Act (FOIA) request in 2013. The data set covers all approved petitions for fiscal years 2010-2012. Each petition is for an individual worker and includes the name of the employer as well as specific characteristics of the worker such as wages, highest education level attained, and worker's country of origin. The data set was cleaned to correct for firm misspellings and to consolidate firm subsidiaries.

A nonimmigrant visa can be an important first step toward permanent residence for many skilled foreign workers, but most never become permanent residents. Even before the emergence of the offshoring of high-skill jobs, many $\mathrm{H}-1 \mathrm{Bs}$ were never converted to permanent residence by employers. Lowell (2000) estimated that at its peak 47 percent of H-1Bs became permanent residents. To analyze this process more closely I estimate permanent sponsorship rates by employer for the top twenty H-1B firms. I do this by using the Program Electronic Review Management (PERM) database, which is kept by the U.S. Department of Labor's Office of Foreign Labor Certification. ${ }^{4}$

4. The data can be found from the U.S. Department of Labor here: https://www.foreignlabor cert.doleta.gov/performancedata.cfm\#dis. 
Employment-based immigration is a four-step process. The first step, sometimes called pre-PERM, is for the employer to complete active recruitment of U.S. workers by advertising in newspapers and collecting applications. ${ }^{5}$ Once the recruitment takes place, and presumably the employer has not found a qualified American applicant, the employer files an "Application for Permanent Employment Certification" (ETA Form 9089) with the U.S. Department of Labor. The data for each of these cases are entered into the PERM database. I have combined the FY2010, 2011, and 2012 data sets. According to the PERM database (the U.S. Department of Labor's Permanent Labor Certification Program Database), H-1Bs accounted for 77 percent of the permanent residence applications, or 142,695 of the 184,682 , in the three-year period FY2010-12. So, it is clear that a large share of the PERM applications is for workers in an $\mathrm{H}-1 \mathrm{~B}$ visa status.

\subsubsection{Different H-1B Uses: Preimmigration versus Way Station}

As mentioned earlier, different employers use the H-1B program either as a bridge to permanent immigration or as a temporary labor mobility program. Even within different divisions of the same company, employers will use its guest worker visas differently - some divisions use it for a conversion to permanent residence while other divisions use it purely for temporary labor mobility. An exemplary case of this divergence is Silicon Valley-based software giant Oracle Corporation. When asked whether Oracle uses the $\mathrm{H}-1 \mathrm{~B}$ program as a bridge to immigration, Robert Hoffman, then lobbyist and vice president for government affairs at Oracle, stated, "More than 90 percent of Oracle's visa workers are trying to stay in the United States and are on the path to permanent residency" (McGee 2007). At nearly the same time as Hoffman's statement, Shahab Alam, an executive of I-Flex (now known as Oracle Financial Solutions), a subsidiary of Oracle, described its use of the H-1B visas as unrelated to permanent residency (NPR Marketplace Radio 2007): "Most of the people coming through us [on H-1B] have no intention of settling in the United States. These are folks who are coming here to do a job, have fun while they can in the United States, and then use this experience in different parts of the world." 6

The government does not directly measure the conversion from temporary to permanent resident, but we can use available data to estimate

5. A number of serious weaknesses in this process have been identified, where firms go through the motions of recruitment with the goal of excluding qualified American workers from being hired. This process was described in a video made by the immigration law firm, Cohen \& Grigsby, in a marketing seminar. The video became viral in 2007 and excerpts can be seen here: http://www.youtube.com/watch?v=TCbFEgFajGU. American worker groups like the Programmers Guild have complained repeatedly about what they describe as "fake PERM ads," where these ads are not bona fide job opportunities.

6. This contrast between Oracle and I-Flex is particularly interesting because, at the time, Robert Hoffman served as the chief spokesperson for Compete America, the primary business and educational coalition lobbying for H-1B increases. Given the significant use of H-1Bs by I-Flex, the only way Hoffman could be faithfully reporting Oracle's use was by excluding I-Flex's numbers in his calculations. In fact, in FY2007, when both of these interviews took 
it. To examine this "bridge to immigration" I introduce a measure I call immigration yield, which is the ratio of PERM applications filed for $\mathrm{H}-1 \mathrm{~B}$ workers to initial $H-1 B$ petitions received by a specific employer. As noted above, detailed PERM applications are available from the U.S. Department of Labor's Office of Foreign Labor Certification. Beginning in 2007, the PERM data included the current visa status (H-1B, L-1, O-1, E-3, etc.) for each employee, so one can calculate the yield for each visa type. Ideally, we would be able to track each individual guest worker to identify whether they are sponsored for, and later granted, permanent residence, but names of workers are considered private and therefore not released in either the H-1B I-129 data nor in the PERM data. The data presented below should be viewed as indicators of the conversion rates for different employers rather than as literal rates. An employer could wait a number of years before beginning the PERM process for its guest workers, so that workers who are not being sponsored at one period could be sponsored at a future time. Another reason is that even after an employer initiates the process for converting a guest worker from an $\mathrm{H}-1 \mathrm{~B}$ there is a lead time before the application appears in the PERM database. The lead times are due to regulatory requirements such as advertising the position in newspapers to search for American workers and for Department of Labor processing. To mitigate these effects I use a three-year period FY2010-12 instead of just a single year. Last, there are so-called priority workers of extraordinary ability or multinational executives or university professors, who are sponsored on EB-1 permanent visas. Those workers are not subject to the labor certification, so their employer can bypass the form that populates the PERM database. In FY2012, EB-1s accounted for 16,286 of the employment-based permanent residences granted, and the majority, 9,209, were for multinational executives on L-1A, a different guest worker visa. The small numbers of $\mathrm{H}-1 \mathrm{Bs}$ who are sponsored through an EB-1 are not likely to bias the conversion rates discussed below. Notwithstanding these limitations the data show clear and distinctive patterns of $\mathrm{H}-1 \mathrm{~B}$ use by employers: some employers use it for purely temporary purposes while others use it as a bridge to permanent immigration.

\subsection{H-1B Use by Offshoring Firms versus Product Firms}

Table 9.1 shows the immigration yields for the top twenty H-1B employers for the three-year period FY2010-12. The top twenty H-1B employers account for a large share of the FY2010-12 visas issued. These visas are

place, I-Flex received $374 \mathrm{H}-1 \mathrm{Bs}$ but applied for permanent residence for only sixteen of its $\mathrm{H}-1 \mathrm{~B}$ workers, an immigration yield of only 4 percent. That is a far cry from the 90 percent Hoffman claimed. And in 2007, I-Flex received more than three times as many H-1Bs as its parent, Oracle, which received 113 worker visas used for intracompany transfers (U.S. Department of Homeland Security 2012). 
FY2010-12 top twenty H-1B employers: Immigration yield

\begin{tabular}{|c|c|c|c|c|c|}
\hline H-1B rank & Firm & $\begin{array}{c}\text { FY2010-12 } \\
\text { new H-1Bs } \\
\text { received }\end{array}$ & $\begin{array}{c}\text { FY2010-12 } \\
\text { PERM } \\
\text { applications for } \\
\text { H-1B workers }\end{array}$ & $\begin{array}{c}\text { Immigration } \\
\text { yield }(\%)\end{array}$ & $\begin{array}{l}\text { Significant } \\
\text { offshoring }\end{array}$ \\
\hline 1 & Cognizant & 17,964 & 2,228 & 12 & $\mathrm{X}$ \\
\hline \multirow[t]{2}{*}{2} & Tata Consultancy & & & & \\
\hline & Services & 9,083 & - & 0 & $\mathrm{X}$ \\
\hline 3 & Wipro & 8,726 & 98 & 1 & $\mathrm{X}$ \\
\hline 4 & Infosys & 6,550 & 129 & 2 & $\mathrm{X}$ \\
\hline 5 & Accenture & 5,799 & 27 & 0 & $\mathrm{X}$ \\
\hline 6 & Microsoft & 4,766 & 4,265 & 89 & \\
\hline 7 & IBM & 3,770 & 462 & 12 & $\mathrm{X}$ \\
\hline 8 & Larsen \& Toubro & 3,286 & 50 & 2 & $\mathrm{X}$ \\
\hline 9 & $\mathrm{HCL}$ & 3,074 & 276 & 9 & $\mathrm{X}$ \\
\hline 10 & Deloitte & 2,850 & 591 & 21 & $\mathrm{X}$ \\
\hline 11 & Mahindra Satyam & 2,535 & 41 & 2 & $\mathrm{X}$ \\
\hline 12 & Intel Corp & 2,036 & 917 & 45 & \\
\hline 13 & Patni-iGate & 1,960 & 186 & 9 & $\mathrm{X}$ \\
\hline 14 & Syntel & 1,646 & 53 & 3 & $\mathrm{X}$ \\
\hline 15 & Google & 1,477 & 705 & 48 & \\
\hline 16 & Amazon & 1,378 & 614 & 45 & \\
\hline 17 & Qualcomm & 1,265 & 1,247 & 99 & \\
\hline 18 & PricewaterhouseCoopers & 1,059 & 392 & 37 & $\mathrm{X}$ \\
\hline 19 & Mphasis & 993 & 106 & 11 & $\mathrm{X}$ \\
\hline \multirow[t]{2}{*}{20} & Synechron & 700 & 26 & 4 & X \\
\hline & Total & 80,917 & 12,413 & 15 & 15 of 20 \\
\hline
\end{tabular}

Sources: H-1B data from USCIS I-129 petitions; PERM data from U.S. Department of Labor, Foreign Labor Certification Data Center.

capped with an annual quota of 85,000 . The top twenty H-1B employers received 80,917 , or 32 percent, of the three years' worth of 255,000 allotted. These firms are a significant determinant of the impact of the H-1B program on the U.S. economy and labor market. The $\mathrm{H}-1 \mathrm{~B}$ program is employer driven and employers have considerable discretion over their use of the program. The employer selects which foreign workers to hire as an $\mathrm{H}-1 \mathrm{~B}$ and which ones to sponsor for permanent immigration. As a result, firm behavior is the significant driver of program impact. How do employers use the H-1B program in relation to permanent immigration? Which employers use the $\mathrm{H}-1 \mathrm{~B}$ program as a bridge to permanent immigration versus those using it for temporary labor? Do H-1B worker characteristics vary across these employers?

What emerges from the analysis is employer use clustered around two business models. The first model is an offshoring business model, in which companies perform most of their work overseas in low-cost countries. Offshoring firms in information technology (IT) include firms that outsource 
most of their work overseas such as Cognizant, Infosys, Wipro, and Tata Consultancy Services and major IT and consulting firms like Accenture, Deloitte, and IBM that have built up significant offshore outsourcing operations. These companies perform most of their work overseas in low-cost countries. ${ }^{7}$ The second business model, in which firms do considerable work in the United States, are product firms that do not provide significant offshoring outsourcing, such as Intel, Qualcomm, and Microsoft.

In the rest of this chapter I contrast these two types of firms along several dimensions by giving statistics on them separately in a single table, with an "A" name for the offshoring firms and a "B" name for the product firms. Thus, tables 9.2A, 9.3A, 9.4A, and 9.5A all refer to the data from the same firms, those I characterize as offshoring firms, while tables 9.2B, 9.3B, 9.4B, and $9.5 \mathrm{~B}$ all refer to data for product firms.

\subsection{Offshoring Firms Have Low Immigration Yields While Product Firms Have High Yields}

The $\mathrm{H}-1 \mathrm{~B}$ visa rankings in table 9.2A show very low immigration yield for most of the major offshore outsourcing firms for FY2010-12, indicating that these firms have little interest in converting their $\mathrm{H}-1 \mathrm{~B}$ employees to permanent residence. These firms are the largest users of the $\mathrm{H}-1 \mathrm{~B}$ program, making up fifteen of the top twenty users. Those fifteen firms alone received nearly 70,000 visas, or 86 percent of the top twenty. The list here also mirrors the largest of the offshore outsourcing firms. The business model of these firms is to transfer labor overseas - not to hire in the United States permanently. In fact, many of these firms hire very few American citizens and, as their immigration yields show, sponsor few $\mathrm{H}-1 \mathrm{Bs}$ for permanent residence (Srivastava and Herbst 2010). Tata Consultancy Services, the largest Indiabased offshore outsourcing firm, did not file an application for a single permanent resident for any of its $\mathrm{H}-1 \mathrm{Bs}$. The pure-play offshore outsourcing firms all have immigration yields at 12 percent or below. Cognizant, the top firm, which is headquartered in the United States, has the highest immigration yield in the group at 12 percent. ${ }^{8}$ IBM is a hybrid firm, with business segments beyond offshoring that include product lines of semiconductors and packaged software. This analysis combines IBM with IBM India, a wholly owned subsidiary of U.S.-based IBM (IBM 2008, exhibit 21). IBM

7. See my policy brief for immigration for the Agenda for Shared Prosperity (Hira 2007), and for a more detailed treatment of the offshore outsourcing phenomenon, see my book, Outsourcing America (Hira and Hira 2008).

8. Even though Cognizant, a spin-off of Dun \& Bradstreet, is based in the United States, its business model is the same as the India-based offshore outsourcing firms. Cognizant's CEO Lakshmi Narayanan served as the chairman of NASSCOM (the Indian industry association for offshore outsourcing) in 2007. 
Offshoring firms: Immigration yield

\begin{tabular}{|c|c|c|c|c|c|}
\hline H-1B rank & Firm & $\begin{array}{l}\text { FY2010-12 } \\
\text { new H-1Bs } \\
\text { received }\end{array}$ & $\begin{array}{l}\text { FY2010-12 } \\
\text { PERM } \\
\text { applications for } \\
\text { H-1B workers }\end{array}$ & $\begin{array}{c}\text { Immigration } \\
\text { yield (\%) }\end{array}$ & $\begin{array}{l}\text { Pure-play } \\
\text { offshoring } \\
\text { firm }\end{array}$ \\
\hline 1 & Cognizant & 17,964 & 2,228 & 12 & $\mathrm{X}$ \\
\hline \multirow[t]{2}{*}{2} & Tata Consultancy & & & & \\
\hline & Services & 9,083 & - & 0 & $\mathrm{X}$ \\
\hline 3 & Wipro & 8,726 & 98 & 1 & $\mathrm{X}$ \\
\hline 4 & Infosys & 6,550 & 129 & 2 & $\mathrm{X}$ \\
\hline 5 & Accenture & 5,799 & 27 & 0 & \\
\hline 7 & IBM & 3,770 & 462 & 12 & \\
\hline 8 & Larsen \& Toubro & 3,286 & 50 & 2 & $\mathrm{X}$ \\
\hline 9 & HCL & 3,074 & 276 & 9 & $\mathrm{X}$ \\
\hline 10 & Deloitte & 2,850 & 591 & 21 & \\
\hline 11 & Mahindra Satyam & 2,535 & 41 & 2 & $\mathrm{X}$ \\
\hline 13 & Patni-iGate & 1,960 & 186 & 9 & $\mathrm{X}$ \\
\hline 14 & Syntel & 1,646 & 53 & 3 & $\mathrm{X}$ \\
\hline 18 & PricewaterhouseCoopers & 1,059 & 392 & 37 & \\
\hline 19 & Mphasis & 993 & 106 & 11 & $\mathrm{X}$ \\
\hline 20 & Synechron & 700 & 26 & 4 & $\mathrm{X}$ \\
\hline
\end{tabular}

Sources: H-1B data from USCIS I-129 petitions; PERM data from U.S. Department of Labor, Foreign Labor Certification Data Center.

India applied for zero PERMs. Its operations are similar to the other pureplay offshore outsourcing firms, and IBM identifies Wipro and Satyam as IBM India's competitors in its annual report (IBM 2008). Two outliers in this list are Deloitte and PricewaterhouseCoopers, with immigration yields of 21 percent and 37 percent, respectively. Both firms are part of the "Big Four" in the accounting industry. They use the H-1B program for multiple purposes that vary across the different business lines. Both have core tax and audit business lines, which use the $\mathrm{H}-1 \mathrm{~B}$ program mostly as a bridge to permanent residence, while their consulting arms, which compete directly with Accenture and IBM in the offshore outsourcing sector, use the H-1B for temporary mobility. It is clear that the offshoring firms have little or no interest in sponsoring their $\mathrm{H}-1 \mathrm{~B}$ workers for permanent residence, and some have been quite clear about it publicly.

Most of the firms in table 9.2A are members of NASSCOM, India's offshore outsourcing trade association. While he served as president of NASSCOM, Som Mittal, a former executive of Hewlett-Packard India, described why the H-1B program is so important to his member firms, "We need for people to travel back and forth between the United States and India to consult on and complete projects" (Herbst 2009). NASSCOM and the Indian government view the $\mathrm{H}-1 \mathrm{~B}$ visa as trade, rather than immigration, policy 
issues. They believe that their primary comparative advantage is low-cost, high-skilled workers, and that $\mathrm{H}-1 \mathrm{~B}$ regulations, such as wage floors and quotas, are nontariff barriers to trade.

\subsubsection{Why Not Hire American Workers?}

How do low immigration yields for offshore outsourcing firms fit into their human resource practices and what does it tell us about their business models? Offshore outsourcing firms have demonstrated little interest in hiring American workers. The business model is reselling labor, and the H-1B workers can be paid less than an American worker. For example, even though Tata Consultancy had more than 10,843 workers in the United States in 2007, only 739 (9 percent) were Americans. Why are these firms not interested in hiring American workers?

Offshore outsourcing firms rely on the $\mathrm{H}-1 \mathrm{~B}$ programs for three principal reasons.

First, it facilitates their knowledge-transfer operations, where they rotate in foreign workers to learn U.S. workers' jobs.

Second, the H-1B program provides them an inexpensive, on-site presence that enables them to coordinate offshore functions. Many functions that are done remotely still require a significant amount of physical presence at the customer site. For example, according to its financial reporting, Infosys's on-site workers, almost all of whom are foreign guest workers, directly accounts for slightly less than half of its overall revenue (Infosys 2009, slide 12). And according to a Tata Consultancy Services executive, $\mathrm{H}-1 \mathrm{~B}$ workers are less expensive than comparable American workers. Then vice president Phiroz Vandrevala described, in an interview with an Indiabased business magazine, how his company derives competitive advantages by paying its visa holders below-market wages: "Our wage per employee is 20-25 percent lesser than U.S. wage for a similar employee," Vandrevala said. "Typically, for a TCS employee with five years' experience, the annual cost to the company is $\$ 60,000-70,000$, while a local American employee might cost $\$ 80,000-100,000$. This (labour arbitrage) is a fact of doing work onsite. It's a fact that Indian IT companies have an advantage here and there's nothing wrong in that. . . The issue is that of getting workers in the U.S. on wages far lower than local wage rate" (Singh 2003). Neeraj Gupta and Brian Keane, veterans of the IT services industry say that the H-1B program allows IT services firms to save 20 percent to 25 percent by hiring an H-1B worker over hiring an American one. ${ }^{9}$

Third, the H-1B program allows the U.S. operations to serve as a training ground for foreign workers who then rotate back to their home country to do the work more effectively than they could have without such training in the United States. A Businessweek story quoted an executive from Wipro

9. Author conversations with Brian Keane and Neeraj Gupta on March 14, 2013. 
describing the company's use of the H-1B program: "Wipro has more than 4,000 employees in the United States, and roughly 2,500 are on H-1B visas. About 1,000 new temporary workers come to the country each year, while 1,000 rotate back to India, with improved skills to serve clients" (Elstrom 2007). Some firms use the H-1B visas for knowledge transfer, where an incumbent worker transfers his detailed knowledge about his jobs to the trainee, with the explicit purpose of laying off their higher-cost American workers. Firms sometimes do the replacement through contractors.

An example of this behavior in 2003 gained congressional attention and was the centerpiece of a number of congressional hearings. In Lake Mary, Florida, Siemens used Tata Consultancy Services to replace its American workers with guest workers earning one-third of the wages. In an awardwinning series, business reporter Lee Howard of The Day newspaper documented how Pfizer was forcing its U.S. workers to train foreign replacements from offshore outsourcers Infosys and Satyam (Howard 2008). In another example, the television ratings firm Nielsen forced its American workers to train foreign replacements working for Tata Consultancy Services. This took place while Nielsen received tax incentives from local government to create jobs (Kruse and Blackwell 2008). And in 2009, workers at Wachovia, which was being bailed out by the government through the Troubled Asset Relief Program (TARP), claimed they were training their foreign replacements on H-1B visas (Bradley 2009).

Southern California Edison's replacement of 500 of its American IT workers with H-1B workers employed at Tata and Infosys was profiled during a U.S. Senate hearing (Grassley 2015). Southern California Edison told its American IT workers that it was replacing them because the $\mathrm{H}-1 \mathrm{~B}$ workers are cheaper. The wage differentials are stark, with the American IT workers earning $\$ 110,000$ while the $\mathrm{H}-1 \mathrm{~B}$ workers replacing them are earning $\$ 65,000$ to $\$ 70,000$ (Hira 2015).

The H-1B visas are vital to the scalability of the offshoring business model, so some firms are "banking" visas, that is, keeping excess H-1B workers in their home countries and sending them to the United States only as the need arises. The firms measure their slack $\mathrm{H}-1 \mathrm{~B}$ visas in terms of utilization rates; that is, the percent of their H-1Bs are actively in the United States. During an earnings call with Wall Street research analysts covering the firm, Infosys's chief operating officer Kris Gopalkrishnan responded to questions about whether it has an adequate number of workers with visas by saying, "It is $37 \%$ of the total visas available right now with Infosys [that are] being used. That means we have remaining $63 \%$ of the people having visas available to put on projects. So it gives us a better utilization rate or-so it gives us the flexibility. We typically get worried when it reaches $50 \%-55 \%$ because that means that we may not be able to find the right people with the visas two [sic] deploy on the project, so $37 \%$ is a comfortable number" (Infosys 2005).

These guest worker visas are so integral to the offshore outsourcing firms 
Table 9.2B

Product firms: Immigration yield

\begin{tabular}{llccc}
\hline H-1B rank & Firm & $\begin{array}{c}\text { FY2010-12 } \\
\text { new H-1Bs received }\end{array}$ & $\begin{array}{c}\text { FY2010-12 } \\
\text { PERM applications } \\
\text { for H-1B workers }\end{array}$ & $\begin{array}{c}\text { Immigration } \\
\text { yield (\%) }\end{array}$ \\
\hline 6 & Microsoft & 4,766 & 4,265 & 89 \\
12 & Intel Corp. & 2,036 & 917 & 45 \\
15 & Google & 1,477 & 705 & 48 \\
16 & Amazon & 1,378 & 614 & 45 \\
17 & Qualcomm & 1,265 & 1,247 & 99 \\
\hline
\end{tabular}

Sources: H-1B data from USCIS I-129 petitions; PERM data from U.S. Department of Labor, Foreign Labor Certification Data Center.

that then-Indian Commerce Minister Kamal Nath called the H-1B the "outsourcing visa" in an interview with the New York Times while arguing for an increase in the H-1B cap (Lohr 2007). In responding to the competitive threat from offshore outsourcing firms like Infosys, many multinational corporations, which until recently have had traditional business models, have moved very aggressively to adopt their own offshore outsourcing business model. The primary business model of these firms is not offshore outsourcing, but they have built up significant offshore outsourcing operations. Some of these firms, such as Hewlett-Packard (HP), have done this through acquisitions (HP acquired EDS and MPhasis), or through subsidiaries, while others have simply transferred work to new employees in low cost countries.

Accenture and IBM provide interesting cases. Accenture has built up its workforce in low-cost countries very quickly. According to its CEO, as of August 2007, Accenture had more employees in India than any other country, including the United States (Chatterjee 2007). Similarly, IBM has increased its workforce in India very dramatically. From a mere 6,000 workers in India in 2003, its headcount rose to 74,000 by 2007 , and is projected to have reached 100,000 by 2010 (D'Souza 2008; McDougall 2006). Given the continuing downsizing of its U.S. workforce, reduced to 115,000 in 2009, India likely became its largest workforce in 2012 (Lohr 2009).

Table 9.2B shows that product firms, which are not in the business of offshore outsourcing, are clustered into two groups with respect to their immigration yields. First, there are firms like Microsoft or Qualcomm that are heavy users of the $\mathrm{H}-1 \mathrm{~B}$ and try to convert a large share of them to permanent residence. Then there is a group, Google, Intel, and Amazon where employers are converting about one-half of their H-1Bs to permanent residence.

\subsection{Other Differences in H-1B Use between Offshoring and Product Firms}

Tables 9.3A and 9.3B show substantial differences in the wage distributions of offshoring firms versus product firms use of the H-1B program. 


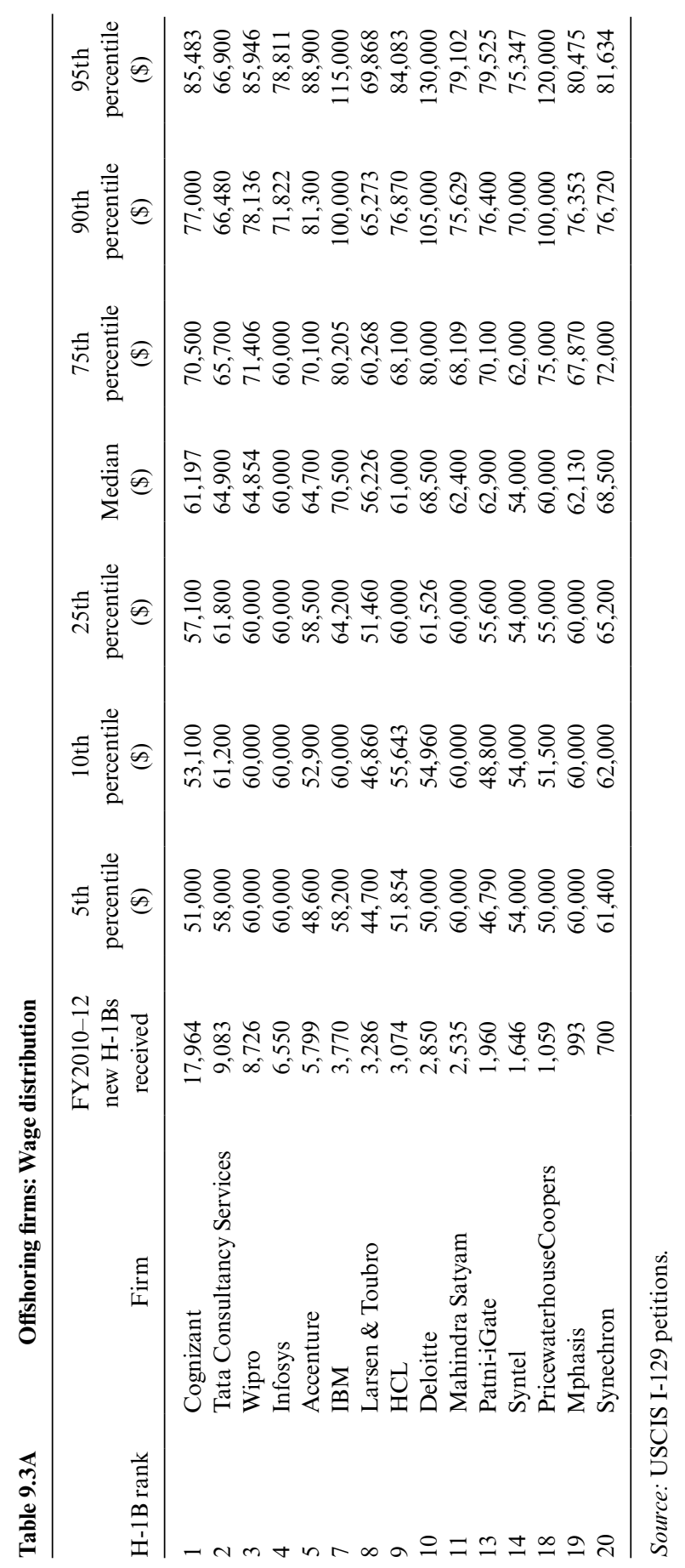




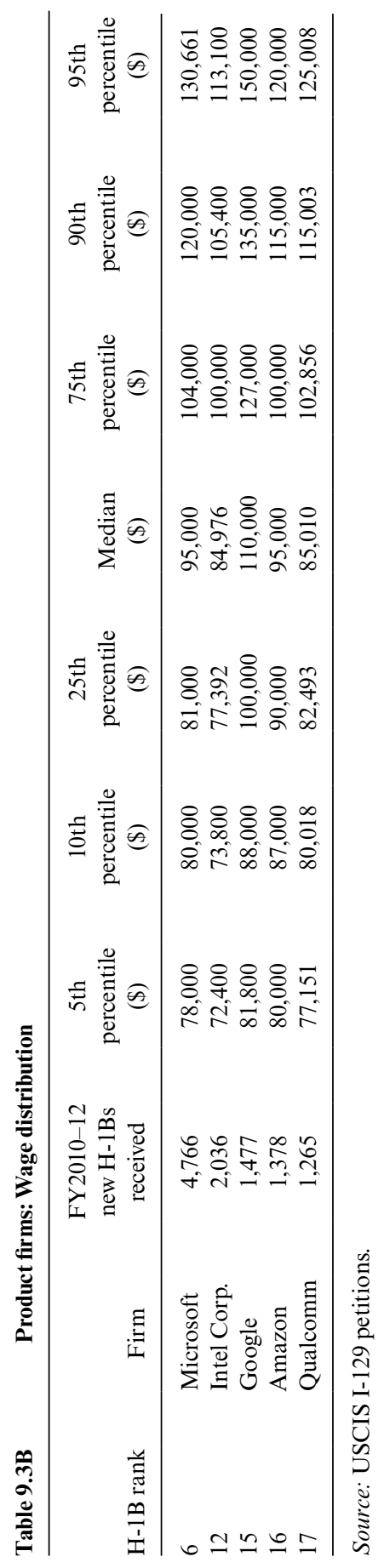

You are reading copyrighted material published by University of Chicago Press. Unauthorized posting, copying, or distributing of this work except as permitted under U.S. copyright law is illegal and injures the author and publisher. 
The firms with significant offshoring in table 9.3A all have lower absolute levels of wages, with medians ranging from $\$ 54,000$ to $\$ 70,500$, compared to the product firms' median wages in table 9.3B that range from $\$ 85,000$ to $\$ 110,000$.

Some pure-play offshore outsourcing firms have very flat wage distributions. For example, Infosys's wage at the 75 th percentile is $\$ 60,000$ and is exactly the same as its wage at the 5th percentile. That means almost 5,000 of Infosys's H-1B workers are paid exactly $\$ 60,000$. This is likely due to the fact that $\mathrm{H}-1 \mathrm{~B}$ regulations are more stringent for heavy users of $\mathrm{H}-1 \mathrm{~B}$ firms (so-called H-1B dependent) that pay workers less than $\$ 60,000$. The $\mathrm{H}$-1B-dependent firms must perform active recruitment and adhere to nondisplacement requirements unless they pay $\mathrm{H}-1 \mathrm{~B}$ workers at least $\$ 60,000$. Infosys is able to achieve regulatory relief by paying at least $\$ 60,000$, but it has little incentive to pay more than that.

Tables 9.4A and 9.4B show a striking difference in the source countries of $\mathrm{H}-1 \mathrm{Bs}$ for the offshoring versus product firms. With the exception of PricewaterhouseCoopers and Deloitte, all of the offshoring firms have more than 90 percent of their H-1Bs come from India. For some, like U.S.-based firms Cognizant and Syntel, virtually all of their H-1Bs are from India. For the product firms, India is still the top source country for H-1Bs, but it isn't nearly as dominant. In the case of Google, China is the top source country for its $\mathrm{H}-1 \mathrm{Bs}$. The product firm reliance on $\mathrm{H}-1 \mathrm{~B}$ workers from India means that many of their workers will be waiting in long lines for permanent residency. Unlike the H-1B program, which has no per-country limits, there are

Offshoring firms: Top source country for $\mathrm{H}-1 \mathrm{~B}$ workers

\begin{tabular}{llcccc}
\hline H-1B rank & \multicolumn{1}{c}{ Firm } & $\begin{array}{c}\text { FY2010-12 } \\
\text { new H-1Bs } \\
\text { received }\end{array}$ & $\begin{array}{c}\text { Top } \\
\text { source } \\
\text { country }\end{array}$ & Number & $\begin{array}{c}\text { Top source } \\
\text { country share } \\
\text { of total (\%) }\end{array}$ \\
\hline 1 & Cognizant & 17,964 & India & 17,898 & 100 \\
2 & Tata Consultancy Services & 9,083 & India & 9,057 & 100 \\
3 & Wipro & 8,726 & India & 8,687 & 100 \\
4 & Infosys & 6,550 & India & 6,341 & 97 \\
5 & Accenture & 5,799 & India & 5,503 & 95 \\
7 & IBM & 3,770 & India & 3,420 & 91 \\
8 & Larsen \& Toubro & 3,286 & India & 3,275 & 100 \\
9 & HCL & 3,074 & India & 3,048 & 99 \\
10 & Deloitte & 2,850 & India & 1,981 & 70 \\
11 & Mahindra Satyam & 2,535 & India & 2,524 & 100 \\
13 & Patni-iGate & 1,960 & India & 1,943 & 99 \\
14 & Syntel & 1,646 & India & 1,642 & 100 \\
18 & PricewaterhouseCoopers & 1,059 & India & 318 & 30 \\
19 & Mphasis & 993 & India & 989 & 100 \\
20 & Synechron & 700 & India & 692 & 99 \\
\hline
\end{tabular}

Source: USCIS I-129 petitions. 
Table 9.4B

Product firms: Top source country for H-1B workers

\begin{tabular}{llclrc}
\hline H-1B rank & Firm & $\begin{array}{c}\text { FY2010-12 } \\
\text { new H-1Bs } \\
\text { received }\end{array}$ & \multicolumn{1}{c}{$\begin{array}{c}\text { Top source } \\
\text { country }\end{array}$} & Number & $\begin{array}{c}\text { Top source } \\
\text { country share } \\
\text { of total (\%) }\end{array}$ \\
\hline 6 & Microsoft & 4,766 & India & 1,382 & 29 \\
12 & Intel Corp. & 2,036 & India & 1,354 & 67 \\
15 & Google & 1,477 & China, People's Republic of & 321 & 22 \\
16 & Amazon & 1,378 & India & 644 & 47 \\
17 & Qualcomm & 1,265 & India & 726 & 57 \\
\hline
\end{tabular}

Source: USCIS I-129 petitions.

country-specific limits within the legal permanent resident quotas. In the case of India, as of February 2015 the backlog times range from ten years for advanced-degree holders and twelve years for those with no more than a bachelor's degree (U.S. State Department 2015, employment-based table).

Tables 9.5A and 9.5B show the H-1B beneficiary's highest level of education, bachelor's degree, master's degree, or doctorate. For the offshoring firms, bachelor's degree is the largest share of its H-1B workforce. For Infosys it accounts for 86 percent. Further, these firms hire virtually no doctorate holders, with IBM being the sole exception. As explained earlier, IBM is a hybrid company with business lines in offshoring as well as products like semiconductors and software. For the product firms, more than half of the H-1B workers for Amazon and Microsoft hold no more than a bachelor's degree. Intel, Google, and Qualcomm all hire some doctorate holders, with nearly one-third of Intel's H-1B workers holding a doctorate. The relatively low level of educational attainment is particularly surprising since much of the public discussion over $\mathrm{H}-1 \mathrm{Bs}$ presents them as recent advanced-degree graduates of U.S. universities. The educational bar for American workers and students to fill these positions is much lower than is widely believed.

\subsection{Conclusion}

To better understand the impacts of the H-1B program on the U.S. economy and labor market as well as for immigration policy, analysts need to examine the very different ways in which firms use the program. This chapter identified those firms that use the $\mathrm{H}-1 \mathrm{~B}$ program as a bridge to permanent immigration versus those that are using it for temporary labor mobility. Among the top twenty H-1B employers, offshoring firms sponsor few, if any, of its H-1B workers for permanent residency while product firms tend to sponsor at higher rates. Further, among the top twenty H-1B employers, offshoring firms tend to pay lower wages, have a flatter wage distribution, and hire H-1B workers with lower levels of educational attainment. And offshoring firms rely on $\mathrm{H}-1 \mathrm{~B}$ workers from India at the virtual exclusion 


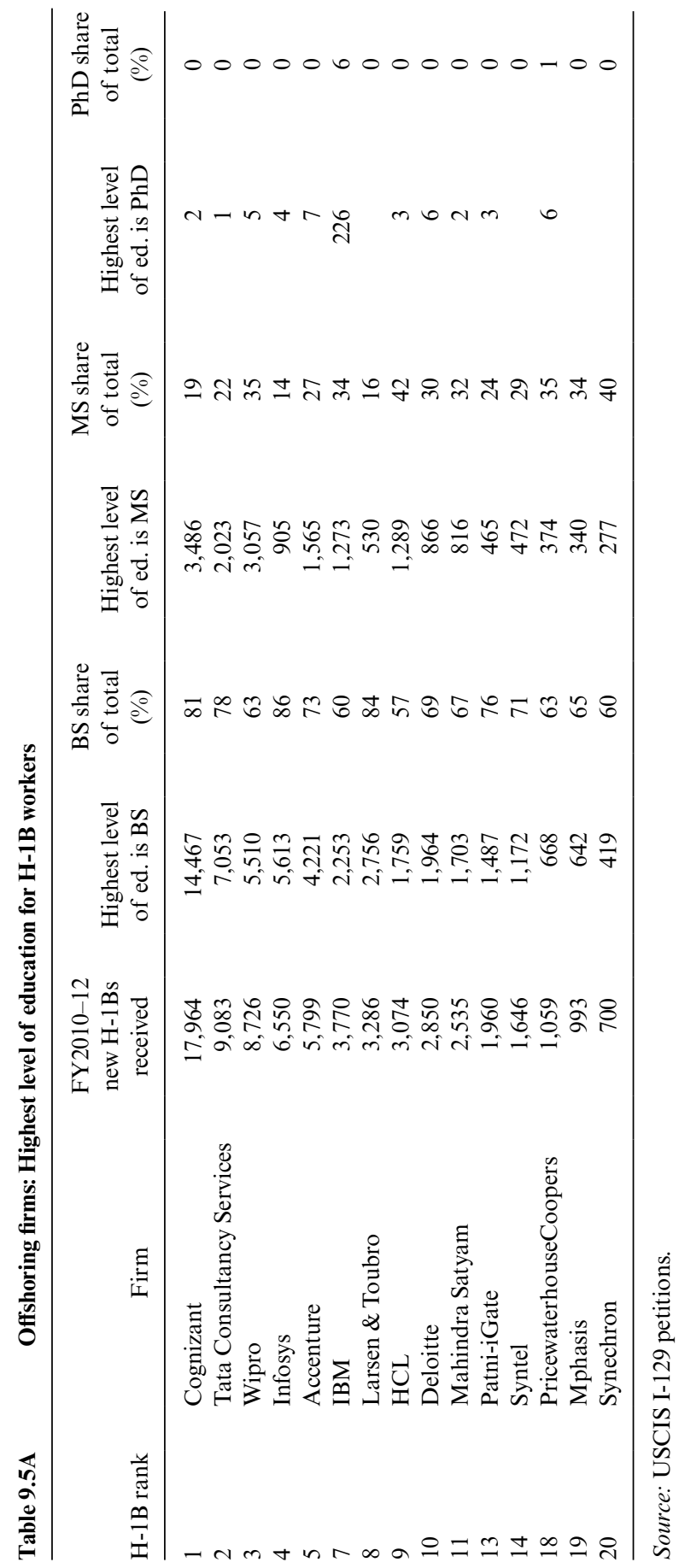




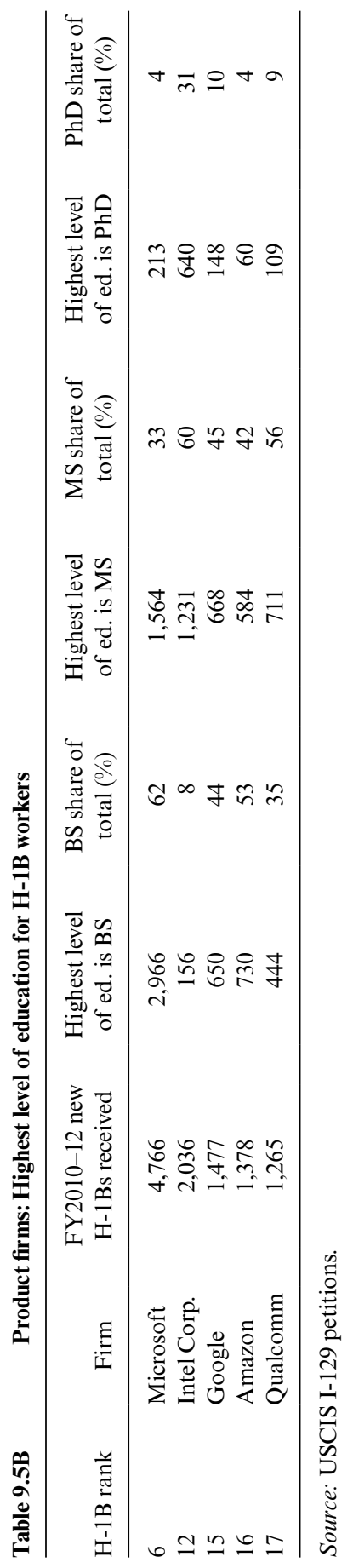

You are reading copyrighted material published by University of Chicago Press. Unauthorized posting, copying, or distributing of this work except as permitted under U.S. copyright law is illegal and injures the author and publisher. 
of workers from any other country. Further analysis of the H-1B data at the firm and industry level, using I-129 microdata, can shed light about program impacts and provide policymakers with a better understanding about how to craft policy changes.

By design, current high-skill immigration policies in the United States place enormous power in the hands of employers. Employers hold the H-1B visa for workers, and employers have complete discretion whether and when to apply for permanent residence for those workers. There are very long backlogs for employment-based immigration for workers from particular countries, such as India. Once an employer applies for permanent residence for the worker, that worker cannot change jobs within the company, even to take a promotion, without hurting his chances for a green card (Ferriss 2006). If a worker who is being sponsored for a green card decides to change jobs, he would have to go to the back of the green card queue. This means that $\mathrm{H}-1 \mathrm{~B}$ workers being sponsored for green cards are essentially tethered to their specific employer for very long periods of time. This reduces the worker's bargaining power and it also negatively affects technological innovation by restricting the movement of workers between employers.

The very large numbers of H-1B workers, coupled with the smaller allotment of employment-based immigration visas, often put guest workers who want to become permanent residents in a state of indentured limbo. The public policy discussion about high-skilled immigration has largely ignored the differences between guest worker visas, like the H-1B, and permanent residence. New policy designs should take into account these differences as well as how the two programs are connected to one another.

\section{References}

Bomey, Nathan. 2008. "H-P Ex-CEO Carly Fiorina: Cut Taxes, Retrain Workers." Michigan Business Review, May 29. Accessed May 29, 2008. http://www.mlive .com/rebrandingmichigan/index.ssf/2008/05/hp_exceo_carly_fiorina_cut_tax .html.

Bradley, Jim. 2009. "Foreign Workers Could Be Replacing Charlotte Bank Employees." WSOC TV.com, Mar. 31. Accessed on Dec. 13, 2009. http://www.wsoctv.com /news/19047187/detail.html.

Chatterjee, Sumeet. 2007. "Accenture to Raise India Staff to 35,000 by August." Reuters, Jan. 29.

D’Souza, Savio. 2008. "IBM Says Double-Digit Sales Growth in India to Stay." Reuters, Nov. 26.

Elstrom, Peter. 2007. "Work Visas May Work against the U.S." Businessweek, Feb. 8. Ferriss, Susan. 2006. "Hired Hands: Wait for Green Card Tries Visa Holders." Sacramento Bee, Aug. 3.

Friedman, Thomas. 2009. “Open Door Bailout.” New York Times, Feb. 10.

Grassley, Charles. 2015. Prepared Statement by Senator Chuck Grassley of Iowa, 
Chairman, Senate Judiciary Committee, at a hearing titled "Immigration Reforms Needed to Protect Skilled American Workers." Mar. 17. Accessed Apr. 8, 2015. http://www.judiciary.senate.gov/imo/media/doc/03-17-15\%20Grassley\%20State ment1.pdf.

Hamm, Steve, and Moira Herbst. 2009. "America's High-Tech Sweatshops.” Businessweek, Oct. 1.

Hennessy-Fiske, Molly, and Jim Puzzanghera. 2007. "Immigration Plan Doesn't Add Up, Critics Say: Businesses Fault the Senate Bill's Point System, Saying It Can't Keep Pace with the Changing Economy.” LA Times, May 24. Accessed Dec. 13, 2009. http://articles.latimes.com/2007/may/24/nation/na-points24.

Herbst, Moira. 2009. "The H-1B Lull Is Only Temporary.” Businessweek, Nov. 2. Accessed Nov. 2, 2009. https://www.bloomberg.com/news/articles/2009-11-02 /the-h-1b-visa-lull-is-only-temporary.

Hira, Ron. 2007. "Outsourcing America's Technology and Knowledge Jobs: HighSkill Guest Worker Visas are Currently Hurting Rather than Helping Keep Jobs at Home." In EPI Agenda for Shared Prosperity Briefing Paper. Washington, D.C.: Economic Policy Institute.

- 2015. Testimony Given in a Hearing before the Judiciary Committee U.S. Senate on "Immigration Reforms Needed to Protect Skilled American Workers." Mar. 17. Accessed Apr. 8, 2015. http://www.judiciary.senate.gov/imo/media/doc /Hira\%20Testimony.pdf.

Hira, Ron, and Anil Hira. 2008. Outsourcing America: The True Cost of Shipping Jobs Overseas and What Can Be Done about It. New York: AMACOM.

Howard, Lee. 2008. "Pfizer to Ax IT Contractors?" The Day, Nov. 3.

IBM. 2008. Form 10-K Annual Report. Dec. 31. Accessed Apr. 8, 2015. https:// www.sec.gov/Archives/edgar/data/51143/000104746909001737/0001047469 -09-001737-index.htm.

Infosys. 2005. "Infosys Technologies Limited Earnings Conference Call (US)." July 12. Accessed Apr. 8, 2015. http://www.infosys.com/investors/reports-filings /quarterly-results/2005-2006/Q1/Documents/transcripts/USEarningsconference -12-07-05.pdf.

2009. Q210 Results, Presentation Made at Press Conference, Results for the Second Quarter ended Sept. 30, 2009. Accessed Apr. 8, 2015. http://www.infosys .com/investors/reports-filings/quarterly-results/2009-2010/Q2/Documents/press -conference-Q2-10.pdf.

Jasso, Guillermina, Vivek Wadhwa, Gary Gereffi, Ben Rissing, and Richard Freeman. 2010. "How Many Highly Skilled Foreign-Born are Waiting in Line for U.S. Legal Permanent Residence?” International Migration Review 44:477-98.

Kruse, Michael, and Theresa Blackwell. 2008. "How Oldsmar Got Global Influence.” Tampa Bay Times, Sept. 19. http://www.tampabay.com/news/business/how -oldsmar-got-global-influence/818379.

Lohr, Steve. 2007. "Parsing the Truths about Visas for Tech Workers." New York Times, Apr. 15.

2009. "Piecemeal Layoffs Avoid Warning Laws." New York Times, Mar. 5.

Lowell, B. Lindsay. 2000. "H-1B Temporary Workers: Estimating the Population." Working Paper no. 12, Center for Comparative Immigration Studies, University of California, San Diego.

Marshall, Ray. 2009. Immigration for Shared Prosperity: A Framework for Comprehensive Reform. Washington, D.C.: Economic Policy Institute.

McDougall, Paul. 2006. "Analyst: IBM to Employ 100,000 Workers in India by 2010.” Information Week, Dec. 4.

McGee, Marianne Kolbasuk. 2007. "With the H-1B Visa Cap Filled in Record Time, 
Reform is in the Air." InformationWeek, Apr. 7. Accessed Apr. 8, 2015. http:// www.informationweek.com/news/global-cio/showArticle.jhtml?articleID=1988 00918\&pgno $=3$.

NPR Marketplace Radio. 2007. "H-1B Visa Just a Ticket to the Way Station." National Public Radio, July 30. Accessed Apr. 8, 2015. http://marketplace.publicradio.org/display/web/2007/07/30/h1b_visa_just_a_ticket_to_the_way_station/.

Singh, Shelley. 2003. "U.S. Visas are not a TCS-Specific Issue.” Businessworld, June.

Srivastava, Mehul, and Moira Herbst. 2010. "The Return of the Outsourced Job." Businessweek, Jan. 11.

Toppo, Gregg, and Icess Fernandez. 2009. "Federal Complaint: Filipino Teachers Held in 'Servitude." USA Today, Oct. 27. Accessed Nov. 4, 2009. http://www .usatoday.com/news/education/2009-10-27-filipino-teachers_N.htm.

U.S. Department of Homeland Security. 2012. "Yearbook of Immigration Statistics: 2008." Table 7. Persons Obtaining Legal Permanent Resident Status by Type and Detailed Class of Admission: Fiscal Year 2012. Accessed Apr. 8, 2015. http:// www.dhs.gov/sites/default/files/publications/immigration-statistics/yearbook /2012/LPR/table7d.xls.

. 2015. "Characteristics of H-1B Specialty Occupation Workers. Fiscal Year 2014 Annual Report to Congress.” Feb. 26. https://www.uscis.gov/sites/default /files/USCIS/Resources/Reports\%20and\%20Studies/H-1B/h-1B-characteristics -report-14.pdf.

U.S. State Department. 2015. "Visa Bulletin for February 2015.” Accessed Apr. 8, 2015. http://travel.state.gov/content/visas/english/law-and-policy/bulletin/2015 /visa-bulletin-for-february-2015.html.

Washington Post Editorial. 2008. "A Recipe for Weakness." Washington Post, June 4. http://www.washingtonpost.com/wp-dyn/content/article/2008/06/03 /AR2008060303102.html. 